\title{
Coal Companies’ Trade Credit Policy
}

\section{Maria SIERPIŃSKA ${ }^{1)}$}

\author{
${ }^{1)}$ Akademia Ekonomiczno-Humanistyczna w Warszawie
}

http://doi.org/10.29227/IM-2020-01-79

Submission date: $28-12-2019$ | Review date: 19-01-2020

\section{Abstract}

The paper presents issues related to the use of trade credit by coal companies during the 2014-2016 downturn and the upturn of 2017-2018 in the coal industry. Coal companies are at both ends of trade credit, as providers and recipients. Research shows that they financed their activities by means of trade credit more widely than they granted it to coal buyers throughout the entire period. In the downturn, coal companies were keener to credit coal buyers than during the boom in the industry thereby suffering an increased risk of not recouping their receivables. This was reflected in the level of provisions for doubtful receivables. The decline in credit granted to buyers during the downturn is corroborated by a decline in the receivables cycle.

Keywords: receivables, credit trade, credit policy

\section{Introduction}

Trade credit is a financial tool widely used in modern business relations. The need to use it to finance companies' operations, especially those with a long operating cycles in companies with large stocks of work-in-progress results from centuries-old payment habits developed by businesses and inadequate access to bank loans. Although other short-term sources of finance such as factoring, forfaiting or issuing of short-term debt securities are becoming increasingly easy to obtain, yet they are too expensive for companies saddled with low profitability figures. These issues are also characteristic of highly capital-intensive industries that use the leverage market to finance their investments, which limits their access to financing of operations. Typical industries include the hard coal mining industry, exhibiting high capital intensity, long investment cycles and long payback periods (Pawłowski, Kustra et al., 2019). All analyses must also take into account the seasonality of coal consumption, the high susceptibility of the mining industry to business cycles, fluctuations in demand for coal and the cyclical nature of coal prices.

The paper aims to assess trade credit policies in coal-mining companies in 2014-2108. The period was divided into two sub-periods: the downturn period of 2014-2016 and the up-turn period of 2017-2018. An attempt was made to verify three research hypotheses:

1. During a downturn in the coal industry, the share of receivables in current assets grows.

2. During an upturn, coal companies scale down the trade credit available to potential recipients.

3. Regardless of the economic situation, coal companies are to a greater extent recipients of trade credit than its providers.

\section{The Nature of and Rationale for Using Trade Credit}

For a buyer, trade credit means delayed payment terms for delivered goods. Therefore, it is a form of crediting the buyer, hence at the buyer's end it is a short-term source of financing of operating activities, alongside bank loans, factoring or issu- ing short-term debt securities. It is most often granted to entities with long-term commercial ties with the supplier. This does not mean that other entities cannot use this source of financing. Companies whose development depends on their business customers may grant these customers more trade credit than banks.

The duration of trade credit depends on numerous factors, both internal and external, conditioned by the environment and its dynamics. "It is emphasized in pertinent literature that these factors most often include: the type and specificity of the economic activity of the sector, industry specifics and the length of the operating cycle, complexity of manufactured products and their utility, payment habits prevailing in the industry, the political and legal situation of the country, economic situation as well as availability and procedural conditions for obtaining other, alternative sources of financing for the operational activity of enterprises" (Nowak, 2014).

Payment times of invoices depend on the value of the transaction, the risk underlying a buyer's crediting and his behaviour in the marketplace. Extended payment terms will encourage the buyer to continue cooperation and show loyalty, but will also create an additional risk for the creditor of not recovering funds. Shorter than customary payment terms for invoices in a given industry may, in turn, cause a decrease in sales revenues and a deterioration of financial results. Selection of trade credit parameters, among others, invoice payment deadlines requires a rational trade credit policy.

For most companies, trade credit is a substitute for bank loans or other alternative sources of financing, such as factoring or issuing short-term debt securities. The extent to which commercial loans are used depends on the financial condition of the lending enterprise and the reputation resulting from the borrower's timely payments. Deferring payment is always associated with a risk of not being able to collect the funds for goods delivered on credit.

D. Zawadzka (2007) indicates that research shows a close link between the willingness to offer trade credit and the credit activity of banks. Enterprises that enjoy better access 
Tab. 1. Share of receivables in the current assets of coal companies (\%). Source: author's own calculations based on financial statements Tab. 1. Udział należności w aktywach obrotowych spółek węglowych (\%). Źródło: obliczenia własne autora na podstawie sprawozdań finansowych

\begin{tabular}{|l|r|r|r|r|r|}
\hline Company & \multicolumn{1}{|c|}{$\mathbf{2 0 1 4}$} & \multicolumn{1}{|c|}{$\mathbf{2 0 1 5}$} & \multicolumn{1}{|c|}{$\mathbf{2 0 1 6}$} & \multicolumn{1}{|c|}{$\mathbf{2 0 1 7}$} & \multicolumn{2}{|c|}{$\mathbf{2 0 1 8}$} \\
\hline Arch Coal Inc. & 14.1 & 11.0 & 21.0 & 20.8 & 22.9 \\
\hline Baotailong New Materials & 13.7 & 23.6 & 12.7 & 5.0 & 1.5 \\
\hline Bayan Resources Tbk PT & 16.2 & 20.0 & 27.3 & 28.7 & 21.7 \\
\hline Belon OAO & 1.4 & 19.5 & 58.2 & 100.0 & 100.0 \\
\hline China Coal Energy Ltd. & 15.5 & 16.4 & 18.4 & 14.7 & 10.7 \\
\hline Corsa Coal Corp. & 45.5 & 35.3 & 16.2 & 36.8 & 51.2 \\
\hline Jastrzębska Spółka Węglowa & 33.6 & 35.7 & 32.7 & 19.5 & 20.5 \\
\hline LW Bogdanka & 44.5 & 35.1 & 26.3 & 27.6 & 42.2 \\
\hline Mechel PAO & 39.8 & 42.2 & 38.1 & 35.4 & 33.3 \\
\hline Mongolian Mining Corp. & 8.1 & 1.1 & 10.4 & 9.3 & 2.5 \\
\hline Peabody Energy Corp. & 33.3 & 17.8 & 23.2 & 25.4 & 23.3 \\
\hline Raspadskaya PAO & 2.9 & 15.5 & 27.6 & 22.3 & 37.2 \\
\hline Warrior Met Coal Inc. & - & 13.2 & 22.7 & 43.8 & 29.5 \\
\hline Whitehaven Coal Ltd. & 33.1 & 26.7 & 37.5 & 29.0 & 36.7 \\
\hline
\end{tabular}

to a bank loan lend their customers to a greater extent. A reduction in a bank's readiness to lend occurs when the lender classifies the entity as high risk category. It refuses to grant a loan or offers it charging a high interest rate on borrowed capital, incorporating into the loan a higher risk premium. The enterprise is then forced to raise capital through business transactions. By negotiating long payment terms for deliveries it signals its inability to obtain a bank loan. "Companies which grant trade credit can assess the recipient's credit risk faster and more accurately than professional financial institutions do. They have more accurate information from the business market, including qualitative information about the recipient's conduct on the market. They can obtain information based on transactions they conclude on the market, as well as from other suppliers. For this reason, theoreticians often refer to the theory of information asymmetry leading to a limitation of loans granted by financial institutions (Burkat \& Ellingsen, 2004).

Trade credit enables enterprises experiencing difficulties in raising capital from traditional sources to function. It may be the last opportunity to survive for companies having problems with access the debt market, an opportunity to obtain a bank loan, or issue bonds and place them on the market which in itself may entail cost of issue beyond their abilities. This is predominantly true for small business entities starting to pursue their business. For such companies, trade credit allows financing the purchase of raw materials and materials for the production of finished goods or commencement of commercial activities.

Petersen and Rajan (1997) proved that enterprises affected by financial dysfunction (lower inclination to incur debt) grant shorter periods of trade credit to their customers while they themselves use the trade credit option offered by suppliers much more often and are themselves more often recipients than providers of such credit.

The premises underlying the use of deferred payment should be seen in the context of the calculation of benefits and costs incurred by parties to business transactions.

Buyers granted trade credit terms can become a source of future cash inflows, which is why suppliers, expecting benefits, are willing to finance them. However, in order to reduce the risk of not being repaid the debt, enterprises grant price discounts for accelerated payment of invoices relative to the contracted deadline. This decreases sales revenues by the value of the discount, which should be treated as the cost of obtaining cash. These discounts must be high enough for buyers to be persuaded to use them. A comparison of the costs of discounts with the cost of bank loans reveals that the cost of trade credit is higher than the cost of bank loans. An enterprise that calculates the profitability of a transaction involving a discount for payment must obtain additional benefits such as opportunities to increase sales in future periods, customer loyalty, good reputation, etc. By monitoring the scope of use of price discounts and the buyers' settlement times, supplier enterprises are in a position to assess the financial standing of their customers. On this basis, they from poor financial standing but with strong growth prospects not through lower product prices, but through broader crediting of operational activity through longer payment periods for invoices. In the period from the delivery of the goods till the time of payment, the company may use its cash to settle growth-related obligations. For example, it can pay loan installments to a bank or leasing installments.

Pertinent literature draws attention to additional (other than financial and transactional) motives prompting business entities to grant trade credit. The most frequently mentioned ones include the use of trade credit for customer verification, sales promotion, price discrimination and economies of scale. Transactional motivators are associated with the efficiency of cash management. The buyers of products and services will decide to defer payment to their suppliers when the efficiency of using current assets exceeds the cost of trade credit. To settle its liabilities, the company would have to convert these assets into cash and incur both transaction and opportunity costs (Zawadzka, 2007).

Motives involving verification and sales promotion refer to exercising influence on the recipient's market through trade credit. Trade credit can, in its own right, be a tool by which the recipient verifies the supplier and its product offer, thereby protecting the recipient from excessive transfer of product-related risk to it. The offer of deferred payments can be a kind of guarantee of the goods quality, a signal for recipients to take advantage of it. In small enterprises that are not well known in the marketplace - the product offer verification period is long. However, it can be shortened by offering recipients deferred payment. "Deferred payment is 
Tab. 1. Share of receivables in the current assets of coal companies (\%). Source: author's own calculations based on financial statements Tab. 2. Udział rezerw na wątpliwe należności jako odsetek ogółu należności w spółkach węglowych w latach 2014-2018 (\%). Źródło: obliczenia własne autora na podstawie sprawozdań finansowych

\begin{tabular}{|l|r|r|r|r|r|}
\hline Company & $\mathbf{2 0 1 4}$ & $\mathbf{2 0 1 5}$ & $\mathbf{2 0 1 6}$ & $\mathbf{2 0 1 7}$ & $\mathbf{2 0 1 8}$ \\
\hline Arch Coal Inc. & 3.0 & 6.2 & 0.0 & 0.0 & 0.0 \\
\hline Baotailong New Materials & 6.0 & 7.9 & 14.7 & 25.0 & 15.0 \\
\hline Bayan Resources Tbk PT & 0.5 & 0.4 & 1.8 & 1.0 & 4.7 \\
\hline Belon OAO & 84.0 & 3.3 & 1.5 & 0.0 & 0.0 \\
\hline China Coal Energy Ltd. & 5.2 & 4.8 & 6.4 & 6.9 & 9.7 \\
\hline Corsa Coal Corp. & 37.5 & 50.8 & 0.0 & 1.1 & 6.3 \\
\hline Jastrzębska Spółka Węglowa & 10.8 & 14.9 & 10.1 & 10.4 & 7.6 \\
\hline LW Bogdanka & 3.1 & 1.0 & 3.2 & 4.0 & 2.8 \\
\hline Mechel PAO & 46.5 & 60.9 & 60.5 & 38.0 & 40.2 \\
\hline Mongolian Mining Corp. & 27.3 & 25.0 & 0.0 & 0.0 & 0.0 \\
\hline Peabody Energy Corp. & 1.1 & 3.0 & 2.8 & 0.9 & 0.9 \\
\hline Raspadskaya PAO & 0.0 & 0.0 & 0.0 & 0.0 & 0.0 \\
\hline Warrior Met Coal Inc. & - & 9.6 & 8.2 & 11.0 & 14.2 \\
\hline Whitehaven Coal Ltd. & 0.0 & 15.6 & 16.5 & 26.9 & 22.0 \\
\hline
\end{tabular}

also used to promote sales and build up stable relationships with customers. It will allow maintaining sales in conditions of falling demand or dynamizing them in favourable market conditions (Afrifa, Padachi, 2014)." Research carried out in Polish companies shows that liberal policies pursued by companies granting trade credit can significantly increase the value of turnover with some contractors, especially those that represent growth sectors and at the same time do not have sufficient own funds. In the SME sector, trade credit is becoming an objective necessity, strongly affecting their development. The lack of deferred payment terms would effectively prevent the implementation of many production or service tasks. In addition, trade credit gives the opportunity to develop positive long-term ties between the provider and the recipient of such credit and affects the stability and durability of relations between them (Nowak, S. Górczyński, 2018). This is extremely important in the context of an economic crisis. These ties allow many business entities to survive in the market.

Apart from the above benefits of trade credit, it also allows to (Kreczmańska-Gigol, 2014):

- maintain liquidity reserves as it temporarily frees cash for purchases in conditions of deferred payment,

- improve cash management,

- reduce transaction costs relative to alternative sources of financing,

- shorten the cash conversion cycle and reduce the financial gap,

- $\quad$ reduce the need for net working capital by increasing liabilities to suppliers,

- maintain the current owners' control over the company due to lack of the need to tap into funds from new share issues.

The vast majority of enterprises are both providers and recipients of trade credit. By becoming a recipient of trade credit, they can in turn partially finance their receivables arising from the delayed settlement by their own buyers. In this context, liabilities to suppliers reduce the need to provide net working capital needed to finance current assets. Resources which are spared in this way can be spent to finance innovation and development projects.

Trade credit can be used by all manners of companies, regardless of their size, and the only limitation in this area is the risk of non-payment and acquiring a reputation as bad payer. It should be emphasized that the essence of this form of financing boils down to trust, because in the period between the delivery of specific goods and the moment of settlement, the supplier has virtually no control over the delivered products or the receivables arising from their delivery. Therefore the relationship to date and the experience resulting from it are an important condition for granting a certain level of credit. A one-off transaction or a mere several transactions do not result in granting this form of financing. At the same time, it is worth noting that the amount of credit granted depends on the counterparty (be it the supplier or the buyer of goods and services) who grants the credit up to a certain precisely defined amount, which constitutes the maximum level of risk that he is willing to incur on account of a specific buyer (Nowak, 2014).

The relative flexibility, ease and speed of obtaining it is an unquestionable advantage of trade credit in comparison with other methods of business financing, as it does not require the lengthy procedure which typically are connected with preparation of solutions in its area (Ziętek-Kwaśniewska, 2016). It is also emphasized that the time needed to grant trade credit to the recipient is usually short, and the procedure used by suppliers to assess a potential customer's solvency is much simpler than the assessment of a company's creditworthiness by banks. It usually does not require collateral, which banks and other commercial financial institutions are obliged to demand. In addition, in the event of late payment, suppliers often show a lot of understanding in a bid not to lose a customer (Bień, 2011).

\section{Receivables in the Structure of Coal Companies' Current Assets}

The weight of receivables in the assets of coal companies was assessed on the basis of the share of receivables in current assets. It was calculated on the basis of the balance sheets of 
Tab. 3. The cycle of receivables from customers and liabilities to suppliers in coal companies in 2014-2018 in number of days. Source: author's own calculations based on financial statements

Tab. 3. Cykl należności od klientów i zobowiązań wobec dostawców w spółkach węglowych w latach 2014-2018 w liczbie dni. Źródło: obliczenia własne autora na podstawie sprawozdań finansowych

\begin{tabular}{|c|c|c|c|c|c|c|}
\hline \multicolumn{2}{|l|}{ Company } & 2014 & 2015 & 2016 & 2017 & 2018 \\
\hline \multirow[t]{2}{*}{ Arch Coal Inc. } & $\mathrm{AR} / \mathrm{R}$ & 26.3 & 16.7 & 34.1 & 27.1 & 29.9 \\
\hline & $\mathrm{AP} / \mathrm{R}$ & 22.4 & 18.2 & 17.7 & 21.1 & 19.1 \\
\hline \multirow[t]{2}{*}{ Baotailong New Materials } & $\mathrm{AR} / \mathrm{R}$ & 42.0 & 80.0 & 41.4 & 15.9 & 4.1 \\
\hline & $\mathrm{AP} / \mathrm{R}$ & 36.9 & 158.4 & 142.1 & 105.0 & 110 \\
\hline \multirow[t]{2}{*}{ Bayan Resources Tbk PT } & $\mathrm{AR} / \mathrm{R}$ & 23.1 & 44.2 & 40.2 & 30.5 & 22.2 \\
\hline & $\mathrm{AP} / \mathrm{R}$ & 74.0 & 53.3 & 17.4 & 21.5 & 19.3 \\
\hline \multirow[t]{2}{*}{ Belon OAO } & $\mathrm{AR} / \mathrm{R}$ & 2.0 & 15.2 & 31.4 & 1600 & - \\
\hline & $\mathrm{AP} / \mathrm{R}$ & 33.3 & 59.1 & 37.6 & 16.8 & - \\
\hline \multirow[t]{2}{*}{ China Coal Energy Ltd. } & $\mathrm{AR} / \mathrm{R}$ & 44.8 & 62.6 & 49.2 & 32.7 & 19.1 \\
\hline & $\mathrm{AP} / \mathrm{R}$ & 106.6 & 117.2 & 109 & 88.4 & 65.7 \\
\hline \multirow[t]{2}{*}{ Corsa Coal Corp. } & $\mathrm{AR} / \mathrm{R}$ & 52.7 & 18.6 & 29.7 & 45.1 & 39.1 \\
\hline & $\mathrm{AP} / \mathrm{R}$ & 60.8 & 30.5 & 61.0 & 71.2 & 39.0 \\
\hline \multirow[t]{2}{*}{ Jastrzębska Spółka Węglowa } & $\mathrm{AR} / \mathrm{R}$ & 41.0 & 28.0 & 43.0 & 31.6 & 39.3 \\
\hline & $\mathrm{AP} / \mathrm{R}$ & 116.5 & 113.8 & 103.5 & 88.0 & 105.6 \\
\hline \multirow[t]{2}{*}{ LW Bogdanka } & $\mathrm{AR} / \mathrm{R}$ & 48.8 & 43.7 & 46.8 & 41.3 & 41.2 \\
\hline & $\mathrm{AP} / \mathrm{R}$ & 81.3 & 52.1 & 64.5 & 64.8 & 68.7 \\
\hline \multirow[t]{2}{*}{ Mechel PAO } & $\mathrm{AR} / \mathrm{R}$ & 46.7 & 38.7 & 32.2 & 29.1 & 28.1 \\
\hline & $\mathrm{AP} / \mathrm{R}$ & 39.6 & 37.9 & 28.2 & 23.2 & 28.4 \\
\hline \multirow[t]{2}{*}{ Mongolian Mining Corp. } & $\mathrm{AR} / \mathrm{R}$ & 41.1 & 7.3 & 35.9 & 10.4 & 3.6 \\
\hline & $\mathrm{AP} / \mathrm{R}$ & 139.2 & 144.2 & 318.2 & 104.0 & 87.6 \\
\hline \multirow[t]{2}{*}{ Peabody Energy Corp. } & $\mathrm{AR} / \mathrm{R}$ & 30.6 & 15.3 & 37.3 & 36.4 & 29.6 \\
\hline & $\mathrm{AP} / \mathrm{R}$ & 24.8 & 21.7 & 22.2 & 25.4 & 18.4 \\
\hline \multirow[t]{2}{*}{ Raspadskaya PAO } & $\mathrm{AR} / \mathrm{R}$ & 8.9 & 130.7 & 312.6 & 167.9 & 154.7 \\
\hline & $\mathrm{AP} / \mathrm{R}$ & 13.5 & 25.3 & 32.7 & 54.0 & 24.9 \\
\hline \multirow[t]{2}{*}{ Warrior Met Coal Inc. } & $\mathrm{AR} / \mathrm{R}$ & - & 19.0 & 71.0 & 42.3 & 36.6 \\
\hline & $\mathrm{AP} / \mathrm{R}$ & - & 9.2 & 5.9 & 8.9 & 8.9 \\
\hline \multirow[t]{2}{*}{ Whitehaven Coal Ltd. } & $\mathrm{AR} / \mathrm{R}$ & 45.5 & 19.5 & 23.3 & 15.8 & 22.8 \\
\hline & $\mathrm{AP} / \mathrm{R}$ & 22.4 & 17.9 & 13.4 & 7.6 & 9.3 \\
\hline
\end{tabular}

the analyzed companies. In order to increase their current assets, companies have to find sources of financing. Meanwhile, enterprises face difficulties in accessing loans, which undermines their liquidity and may lead to a hostile takeover or even bankruptcy.

2014-2016 witnessed a large drop in coal prices and a decline in sales revenues (Report 2019). During a period of decline in coal sales and building up of stocks of coal, the share of receivables in these assets should be lower than during a boom. This trend occurred only in a few large coal corporations (Arch Coal, Bayan, Belon, Mongolian Coal, Raspadskaya, Warrior), while in a few others (Baotailong, China Coal, JSW, Mechel and Warrior) a reverse trend occurred. Companies reduced production and waited to recoup their receivables longer, which increased the share of receivables in current assets. In several companies (Corsa Coal, Peabody, Whitehaven) it is not possible to ascertain a clear trend in the two analyzed sub-periods.

The author's research did not confirm the first research hypothesis put forward in the introduction on an increase in the share of receivables in current assets during a downturn. In several companies this share increased, in a few it decreased, while three companies pursued a relatively stable trade credit policy, which did not translate into major changes in the share of receivables in current assets.
In the balance sheet receivables are presented at net value or amounts to be recouped from contractors less provisions for debts which are doubtful, difficult to recover or lost due to the debtor's bankruptcy. Polish coal companies create revaluation write-downs of receivables and recognize them as other operating costs. Write downs of interest arising from overdue payments are recognized as financial costs. The manner and level of revaluation write-downs is governed by the provisions of art. 35b.1 of the Accounting Act and IAS 39, paragraphs 58 and 59. Table 2 presents the share of provisions for receivables as a percentage of total receivables in coal companies.

The level of provisions set up in coal companies varies considerably from company to company. A vast majority of companies set up provisions for doubtful receivables in 2014-2016. In the subsequent years, the level of provisions declined. In 2014, Belon charged $84 \%$ of receivables to costs. Mechel on the other hand charged to costs from 40 to $60 \%$ of its receivables each year. Attention should be paid to the share of provisions in receivables in Polish coal companies. In 2014-2017, Jastrzębska Spółka Węglowa charged to costs an average of $10 \%$ of its receivables. In 2018 , the boom year in the coal industry, provisions in the company dropped to $7.6 \%$. In LW Bogdanka, revaluation write-downs of receivables in the period ranged between $3 \%$ and $4 \%$. 


\section{Trade Credit Policy During a Downturn and an Upturn in the Coal Industry}

This analysis of companies' trade credit policy is aimed at determining whether the economic situation has an impact on the trade credit policy in mining companies. These companies provide credit and at the same time benefit from trade credit terms granted them in the form of deferral of payment dates of their suppliers' invoices. The results of global research presented by J. Franc-Dąbrowska and M. Porada-Rochon show that companies reporting a deterioration of their financial condition after the crisis received about 3-4\% fewer goods on credit compared to companies in good financial condition. The first of these groups of entities repaid credit to suppliers four days faster than the group boasting good financial condition (compared to the period before the crisis).

Analysis of the impact of the economic situation in the coal industry on the level of use of trade credit shows that it decreased in the wake of the crisis. This may be due to a lower share of companies purchasing coal on deferred payment terms. The downturn worsened the financial standing of many businesses. Some went bankrupt, while others were taken over by companies boasting a better financial standing, thereby reducing the number of companies operating on the coal market. Data presented in table 3 show that the twelve surveyed companies shortened their receivables cycles. This means that the second research hypothesis was positively verified, with coal companies reducing the scope of trade credit granted to recipients during the economic downturn. Faster collection of sales revenues enabled more efficient settlement of liabilities. The cycle of liabilities to suppliers in 2017-2018 was shorter than in previous years. This situation can be observed in 2017 in relation to the previous year in half of the analyzed companies. In 2018, liabilities cycles lengthened due to increased purchases of assemblies, machine parts and materials securing the increase in production.

The trade credit policy was assessed based on the length of the cycle of receivables from suppliers and payables to customers. They were calculated based on surveyed companies' financial statements from the analyzed years. Receivables and liabilities alike were compared to sales revenues, which ensured comparability of calculated ratios. More than one in two companies (9 out of 14) had a much longer cycle of liabilities owed to customers than the cycle of receivables from customers, implying that in the analyzed period these companies were recipients of trade credit. Their policy of broader use of trade credit than of granting the same to recipients did not change because of changed economic situation. Only one of the companies i.e. Belon was a recipient of trade credit during the downturn and its provider during the boom. During the downturn, several companies' liabilities cycle exceeded 100 days. Jastrzębska Spółka Węglowa was one of them. Suppliers of Mongolian Coal waited an extremely long 318 days for their settlements in 2016. Attention should also be paid to the huge payment gridlocks in the Russian company Raspadskaya PAO. In 2016, the last year of the downturn, the company waited 313 days to collect its receivables. Meanwhile, in the second Russian company Mechel PAO, this cycle in 20152018 did not exceed 30 days. The liabilities cycle was very similar to the receivables cycle. Relatively small differences between the receivables and liabilities cycles were reported by the American companies Peabody and Arch Coal Inc. In the Polish company Lubelski Węgiel Bogdanka, in 2016-2018 the difference in payment of liabilities compared to the receivables cycle was an average of 25 days. During the boom in the coal industry, the receivables cycle in this company shortened from 48 days in 2014 to 41 days in 2017-2018. The data presented in the paper only partially confirmed the third hypothesis put forward in the introduction according to which coal companies, regardless of the economic situation, are buyers of trade credit.

\section{Conclusions}

To sum up, it should be emphasized that trade credit is an important financial instrument of revenue and expense planning both for its providers and recipients. For providers, trade credit facilitates retention of existing customers, acquisition of new ones and building new distribution channels, as well as acquisition of new sales markets. This form of crediting enables financing of sub-suppliers of parts and assemblies necessary to maintain production continuity. A rational trade credit policy may also increase the value of turnover with contractors in dynamically growing industries, which contributes to GDP growth of a given country. For the receiving company, trade credit is a cost-free source of financing of operational activities. It allows purchasing of raw materials and materials needed for production without having to take bank loans. This increases the development opportunities of many small businesses. The sustainability of business relationship promotes development of a number of principles and rules that affect the durability and stability of relationships with customers. In addition, these increase trading security and reduce contracting costs related to debt collection or loss. 


\section{Literatura - References}

1. Afrifa, G.A., Padachi, K. Working capital level influence on SME profitability Journal of Small Business and Enterprise Development, 2014, 1(23) pp. 44-63.

2. Bień, W.(2011). Zarządzane finansami przedsiębiorstwa. Difin, Warszawa, pp. 168 -169.

3. Burkat, M., Ellingsen, T. (2004) In-kind finance: theory of trade credit, American Economic Review, 3 (94), pp.569590.

4. Franc-Dąbrowska, J., Porada-Rochoń, M.(2012). Kredyt kupiecki a sytuacja finansowa małych i średnich przedsiębiorstw w warunkach niestabilnego otoczenia, w:Finanse w niestabilnym otoczeniu -dylematy i wyzwania, Studia Ekonomiczne H. Zadora, G. Łukasik (red.), no 107, pp.169 -177.

5. Kozłowska, A. (2018). Próba identyfikacji podstawowych czynników determinujących jakość sprawozdań finansowych Prace Naukowe Uniwersytetu Ekonomicznego we Wrocławiu, Research Papers of Wrocław University of Economics, no 503, pp. $246-258$.

6. Kreczmańska-Gigol K. (2014). Kredyt kupiecki, w: Finansowanie przedsiębiorstwa. Ujęcie teoretyczno-praktyczne, J. Szlęzak-Matusewicz, P. Felis,(red.) Wolters Kluwer, Warszawa, p. 154.

7. MIĘDZYNARODOWY STANDARD RACHUNKOWOŚCI 39 Instrumenty finansowe: ujmowanie i wycena Dziennik Urzędowy Unii Europejskiej L 320/270, 29.11.2008 https://polanskiaudyt.pl/wp-content/uploads/2012/11/ MSR-39-Instrumenty-finansowe-ujmowanie-i-wycena.pdf 4.04.2020

8. Nowak, D. (2014), Rola i znaczenie kredytu kupieckiego, Zeszyty Naukowe Uniwersytetu Szczecińskiego, 802, Finanse, Rynki Finansowe, Ubezpieczenia, no 65, pp. 815 -827.

9. Nowak, D., Górczyński S.(2018). Kredyt kupiecki w badaniach jakościowych, Zeszyty Naukowe Uniwersytetu Szczecińskiego, Finanse, Rynki Finansowe, Ubezpieczenia, no 1 (91), pp. 205 -2017.

10. Pawłowski, S. Kustra, A., Kozieł, D. (2019). Wydatki związane z pracami eksploracyjnymi -nakłady inwestycyjne czy koszty operacyjne?, Inżynieria Mineralna,R.21, no 1, pp. 341 -346.

\section{Polityka kredytu kupieckiego w spółkach węglowych}

$W$ artykule zaprezentowane zostały problemy korzystania przez spółki weglowe z kredytu kupieckiego w okresie dekoniunktury (2014-2016) i koniunktury (2017-2018) w branży węglowej. Spółki te są równocześnie dawca i biorca tego kredytu. Badania wykazały, że spółki węglowe w całym badanym okresie szerzej finansowały się kredytem kupieckim niż same tego kredytu udzielały odbiorcom węla. W okresie dekoniunktury spótki te szerzej kredytowały odbiorców wegla zwiększając ryzyko nieodzyskania należności niż w okresie koniunktury w branży węglowej. Znalazło to wyraz w poziomie rezerw tworzonych na należności wątpliwe. Na ograniczenie zakresu kredytowania odbiorców w okresie koniunktury wskazuje spadek cykli należności.

Słowa kluczowe: należności, kredyt kupiecki, polityka kredytowa 